\title{
NUMERICAL METHOD APPROACH TO ANALYSIS OF DRAINAGE CHANNELS OF PIT-3 WEST BANKO TANJUNG ENIM
}

\author{
ARIf SATRIa RUSMANA ${ }^{1}$, ACHMAd SYARIFUdin $^{1 *}$ \\ HengGar Risa Destania ${ }^{2}$ \\ ${ }^{1}$ Department of Civil and Environment Engineering,Universitas Bina Darma, Palembang, Indonesia \\ ${ }^{2}$ Department of Civil Engineering, Indo Global Mandiri University, Palembang \\ *Corresponding author: achmad.syarifudin@binadarma.ac.id \\ (Received: 8 October 2021; Accepted: 1 December 2021; Published on-line: 1 March 2022)
}

\begin{abstract}
The drainage network system should be designed to accommodate normal flow rates, especially during the rainy season. This means that the capacity of the drainage channel has been calculated to accommodate the water discharge that occurs so that the area in question does not experience puddles or the channel can to be function properly. For this reason, research is needed to analyze the ability of the ex-coal mine drainage channel in PIT3 West Banko Tanjung Enim. The research was carried out with the help of the HEC-RAS software program to see the changes in the water level in the drainage channel where the water was overflowing from the channel body. The results showed that all the section profiles of the drainage channel $\left(\mathrm{P}_{1}\right)$ till $\left(\mathrm{P}_{10}\right)$ were still in the safe condition or the channel was still stable (stable channel).
\end{abstract}

KEY WORDS: Drainage channel, IDF curve, HEC-RAS Program, Stable channel

\section{INTRODUCTION}

Flood disaster has become a routine phenomenon in the rainy season that spreads in various river basins (DAS) in most parts of Indonesia. The number of flood events in the rainy season during the last 3 years has continued to increase. The number of human victims, property losses, public/social facilities and infrastructure, transportation infrastructure, and agricultural / irrigation infrastructure [1].

The problem of rainfall as a contributing factor, the occurrence of disasters is also inseparable from the damage to environmental ecosystems in watersheds and the poor management of water resources. The existence of land degradation causes an increase in the surface runoff coefficient. The upstream watershed area, which is a recharge area, will be more susceptible to drought. On the other hand, the downstream area is prone to flooding. Inundation/flooding is experienced by urban areas located in the lowlands and areas located in the highlands. A flood or puddle in an area occurs when the system that functions to accommodate the puddle cannot accommodate the flowing discharge; this is a result of three possibilities: decreased system capacity, increased water flow rate, or a combination of both [2].

The drainage network system in an area should be designed to accommodate normal flow rates, especially during the rainy season. The capacity of the drainage channel has been calculated to accommodate the water discharge that occurs so that the area in question does not experience inundation or flooding. If the drainage system's capacity decreases due to various 
reasons, even the normal discharge cannot be accommodated by the existing system. Meanwhile, the causes of decreased drainage capacity include a lot of sediment, physical damage to the network system occurs, and the existence of other buildings on top of the network system. At certain times during the rainy season, there is often an increase in flow rates, or there has been an increase in discharge due to various reasons, so the capacity of the existing system can no longer accommodate the flow rate, resulting in flooding in an area. Meanwhile, the causes of increased discharge include unusually high rainfall, changes in land use, environmental damage to river basins (Watershed) in an area. Then if an urban or area decreases the system capacity while there is an increase in flow rate, the flood will increase, both in frequency, area, depth and duration [3].

The definition of a system here is a drainage network system in an area. In contrast, the drainage system, in general, can be defined as a series of water structures that function to reduce and remove excess water (flood) from an area of land so that the land can be used optimally. Hence, the drainage system is the engineering of infrastructure in an area to overcome inundation-flood [4].

Bukit Asam is a state-owned company engaged in the mining industry. In the process of mining activities, PT. Bukit Asam applies the open-pit mining method. The open-pit method is a mining method in which all mining activities and activities are carried out on or relatively close to the earth's surface, and the workplace is directly related to the outside air.

The disadvantages of the open pit method are that it requires a place for large piling up of land cover, disturbing the landscape, decreasing environmental quality, work that is highly dependent on weather/season conditions, scattered mechanical tools, and limited excavation. Based on these shortcomings, the weather or season is one of the main factors affecting the mining operation using the open-pit method. The weather condition in question is water (rain) in the mining area [5].

The impact is caused by water entering the mining site if it is not properly managed. The work location will be flooded, causing damage to road bodies, decreasing work efficiency, and threatening employees' safety and health. It is necessary to apply an optimal runoff system to anticipate this problem.

Based on the description above, it is necessary to study the drainage network system in the West Banko Tanjung Enim coal mine area so that ex-mining water can be flowed according to the principle of flow hydraulics with the help of the HEC-RAS program. HEC-RAS 4.1.0 is a program that can model unstable flow with a one-dimensional view with a more accurate geometric modelling. Thus, this study aimed to analyze the ability of the ex-coal mine drainage channel in PIT-3 West Banko Tanjung Enim

The approach points for modeling a river or channel cross section can be made more than some other one-dimensional unstable flow programs are often used. Thus, the depiction of each cross-section of each profile using the HEC-RAS program will be closer than before. Simulation with HEC-RAS 4.1.0 aims to determine the longitudinal profile of the river, maximum water level, and flow velocity. In addition, this model can also modify the channel view to get a channel view that can anticipate the planned flood discharge. Modelling that will be discussed consists of 3 studies: the existing model, sluice gates, and pumping systems [6]. 


\section{METHOD}

This research was conducted in Tanjung Enim, located in the IUP (Mining Business License) West Banko, where there are four holes (Pit), namely West Pit 3, East Pit 3, Pit 1 East and Pit 1 North (Fig. 1).

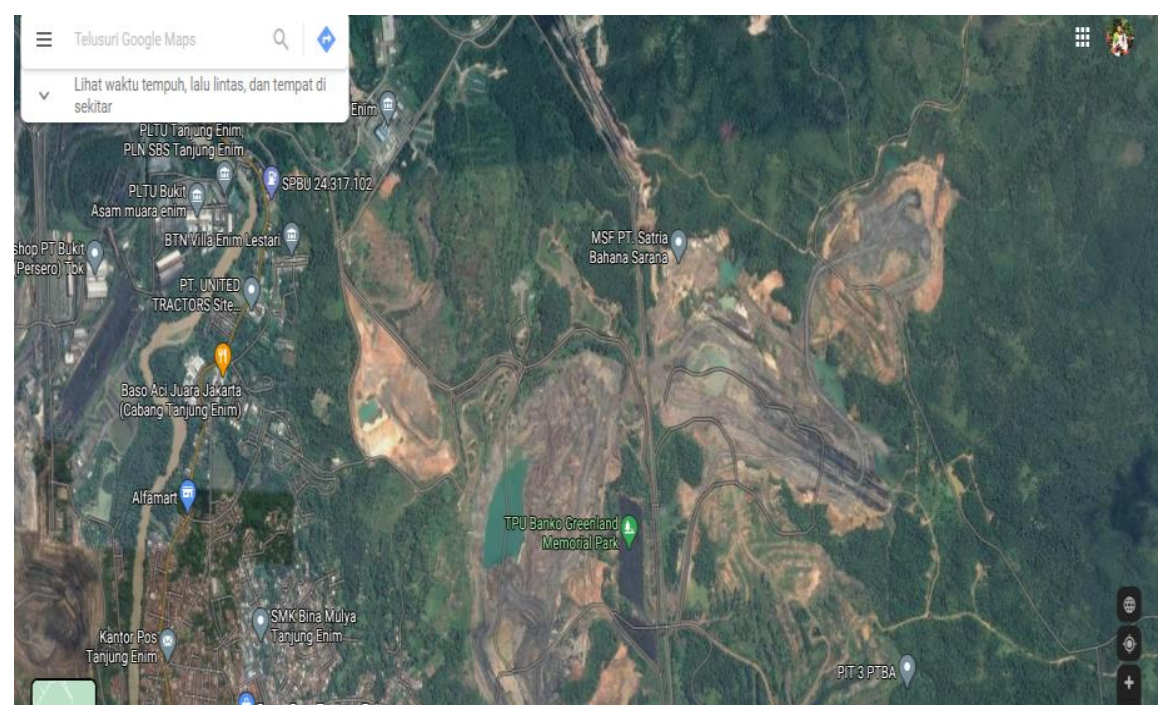

Fig. 1. Research location PIT-3 PTBA

The materials used in this study include collecting rainfall data (secondary data) to analyze rainfall with a certain return period and topographical surveys to obtain cross-sectional and longitudinal profile images of the channels connected to the existing storage ponds.

Rainfall data were used to calculate rainfall intensity, but previously the concentrationtime was calculated. Then the rainfall frequency intensity curve (IDF-Curve) is made and calculates the planned discharge for each specific return period.

\section{RESULT AND DISCUSSION}

The results of the analysis of the frequency of rainfall for each period is 10-minute. The rainfall intensity data then was used to get the IDF curve and its shape, shown in Fig. 2.

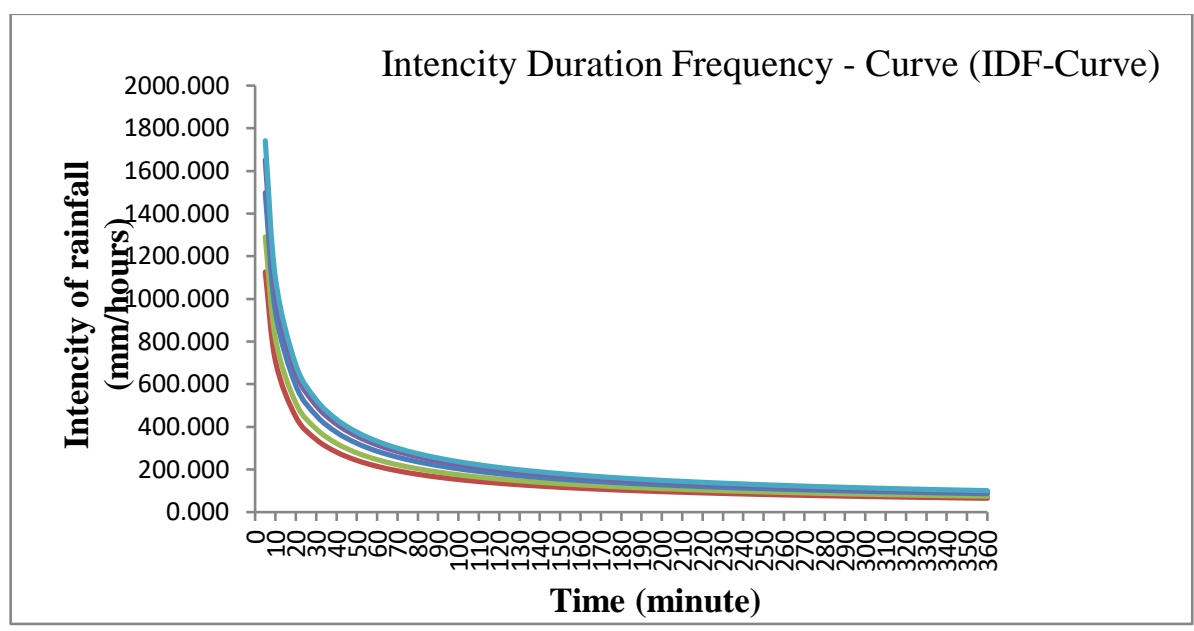

Fig. 2. IDF (Intensity Duration Frequency) Curve 


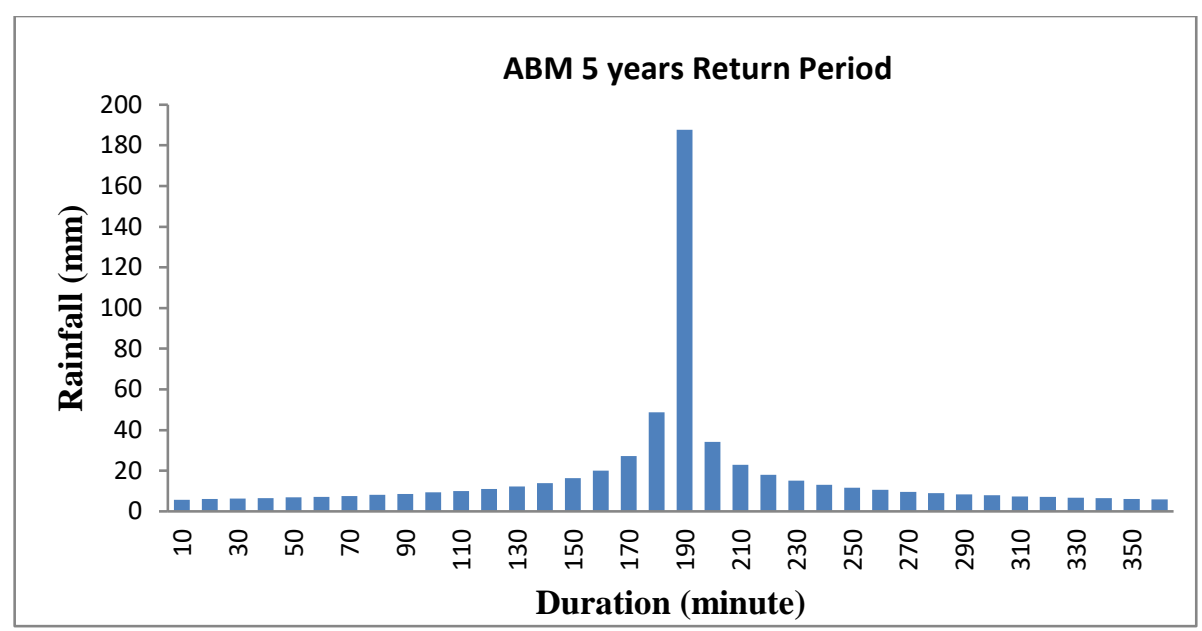

Fig. 3. Hyetograph with the ABM Method for a 5 Year Return Period

\subsection{Flow Discharge}

To calculate runoff discharge using the Rational Formula. The results are as in Table 1.

Table 1: The results of the calculation of runoff discharge

\begin{tabular}{ccccc}
\hline No. & $\mathbf{R}$ & $\mathbf{R}_{\mathbf{2 4}}(\mathbf{m m})$ & $\mathbf{I}(\mathbf{m m} / \mathbf{h o u r})$ & $\mathbf{Q}\left(\mathbf{m}^{\mathbf{3}} / \mathbf{s e c}\right)$ \\
\hline $\mathbf{1}$ & 5 & 619,771 & 454,8194 & 41.36 \\
$\mathbf{2}$ & 10 & 710,154 & 521,1472 & 47.29 \\
$\mathbf{3}$ & 20 & 824,343 & 604,9449 & 54.90 \\
$\mathbf{4}$ & 50 & 909,054 & 667,1106 & 60.54 \\
$\mathbf{5}$ & 100 & 958,292 & 703,2436 & 63.82 \\
\hline
\end{tabular}

\subsection{Simulation Results}

After all data such as flood, the discharge has been inputted into the HEC-RAS Program. The data is running, and the results are seen. Each return period discharge is seen in each crosssection.

The pattern of water level movement in the ex-mining flow channel at Pit-3 West Banko PTBA is as shown below: 


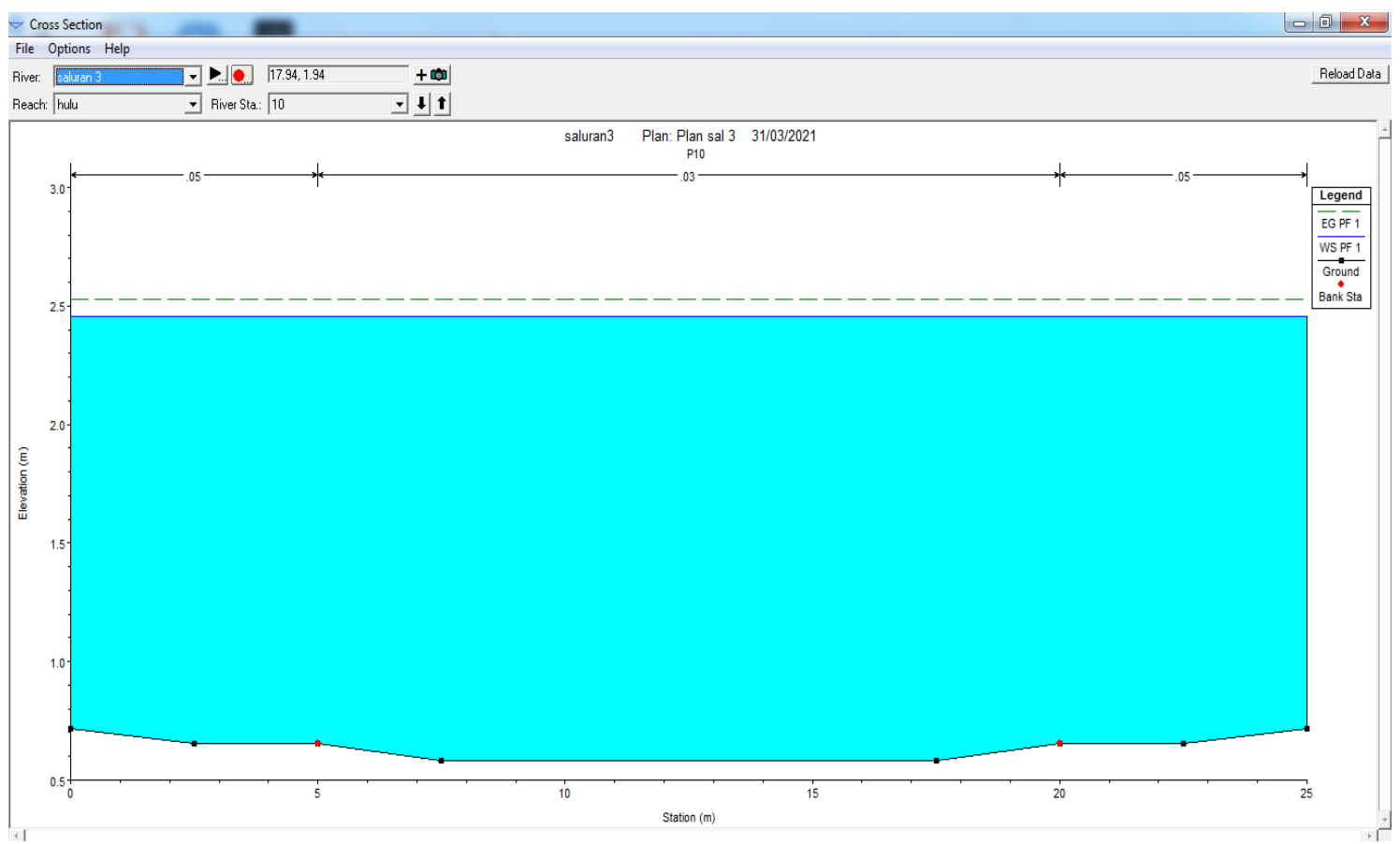

Fig. 4. The pattern of water flow movement in the P-10 channel

In Fig. 4. that the channel does not increase the water level in the channel. This means that the P-10 channel does not overflow, and this condition is due to the influence of the holding pond.

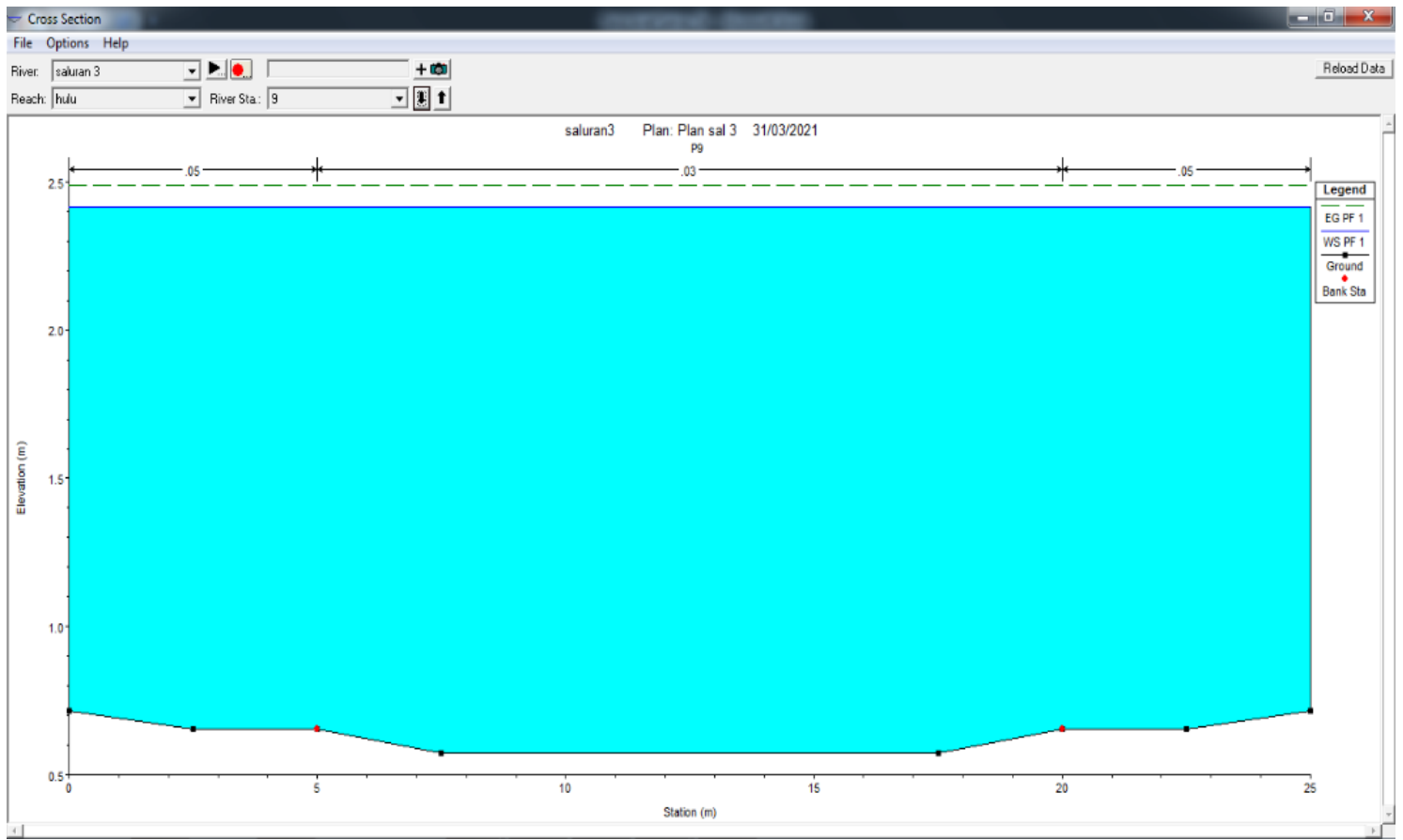

Fig. 5. The pattern of water flow movement in the P-9 channel

In Fig. 5, the channel does not increase the water level in the channel. This means that the P-9 channel does not overflow, and there is little influence on the presence of a storage pool, increasing flow in the channel. 


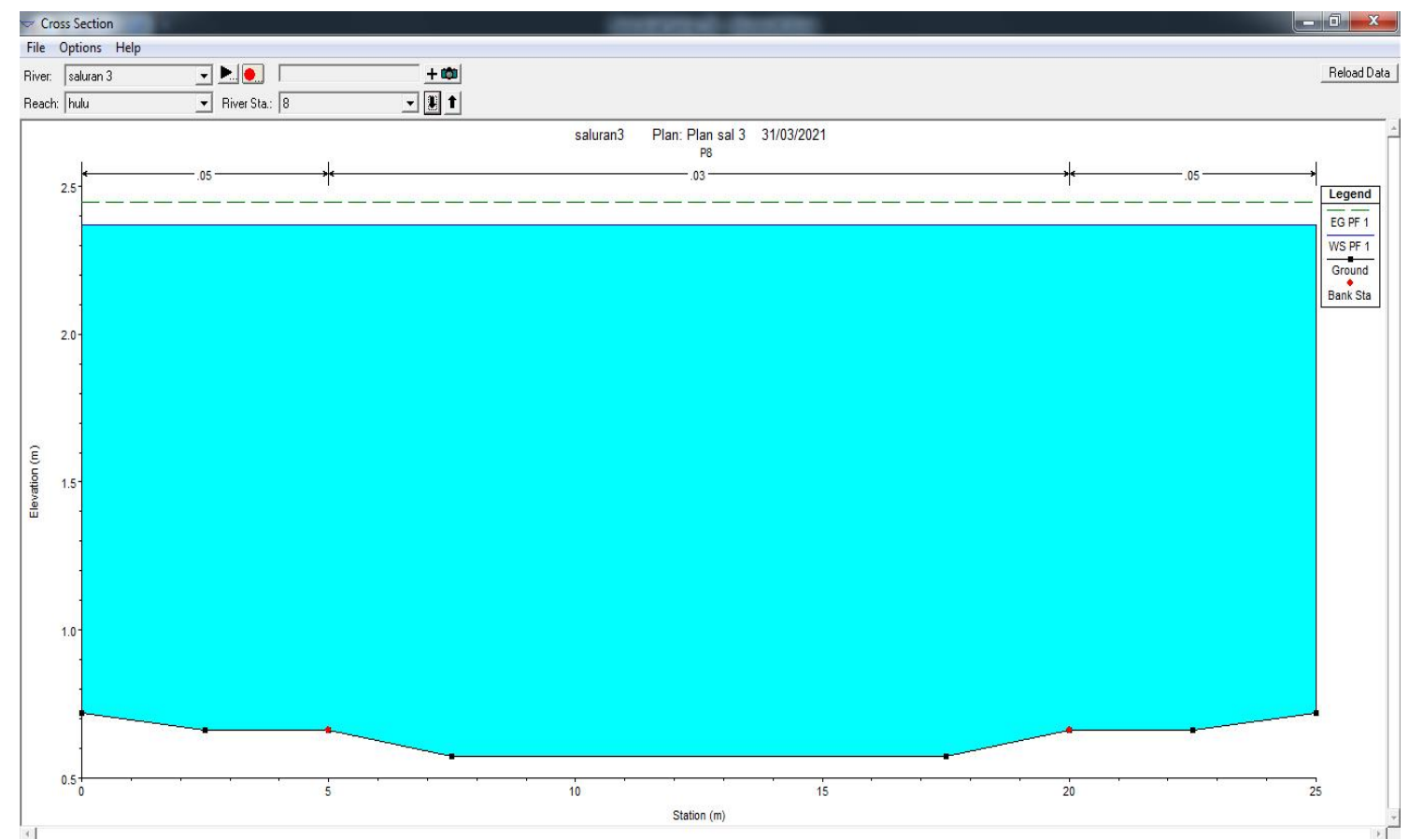

Fig. 6. The pattern of water flow movement in the P-8 channel

In Fig. 6, the channel does not increase the water level in the channel. This means that in the P-8 channel, there is no overflow, and there is little influence on the presence of a storage pool, increasing flow in the channel.

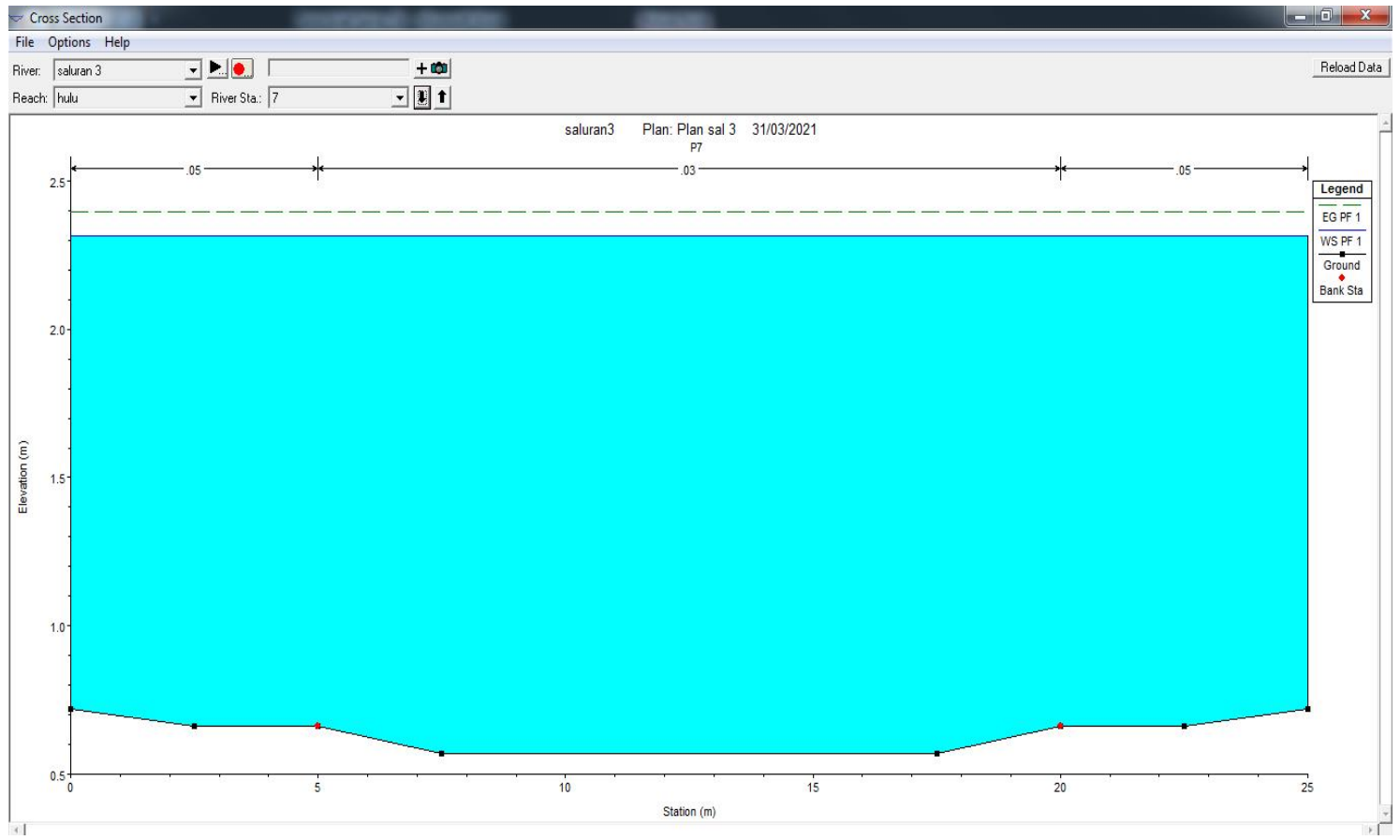

Fig. 7. The pattern of water flow movement in the P-7 channel

In Fig. 7, the channel does not increase the water level in the channel. This means that the P-7 channel does not overflow and has a little effect due to a storage pool, increasing flow in the channel. 


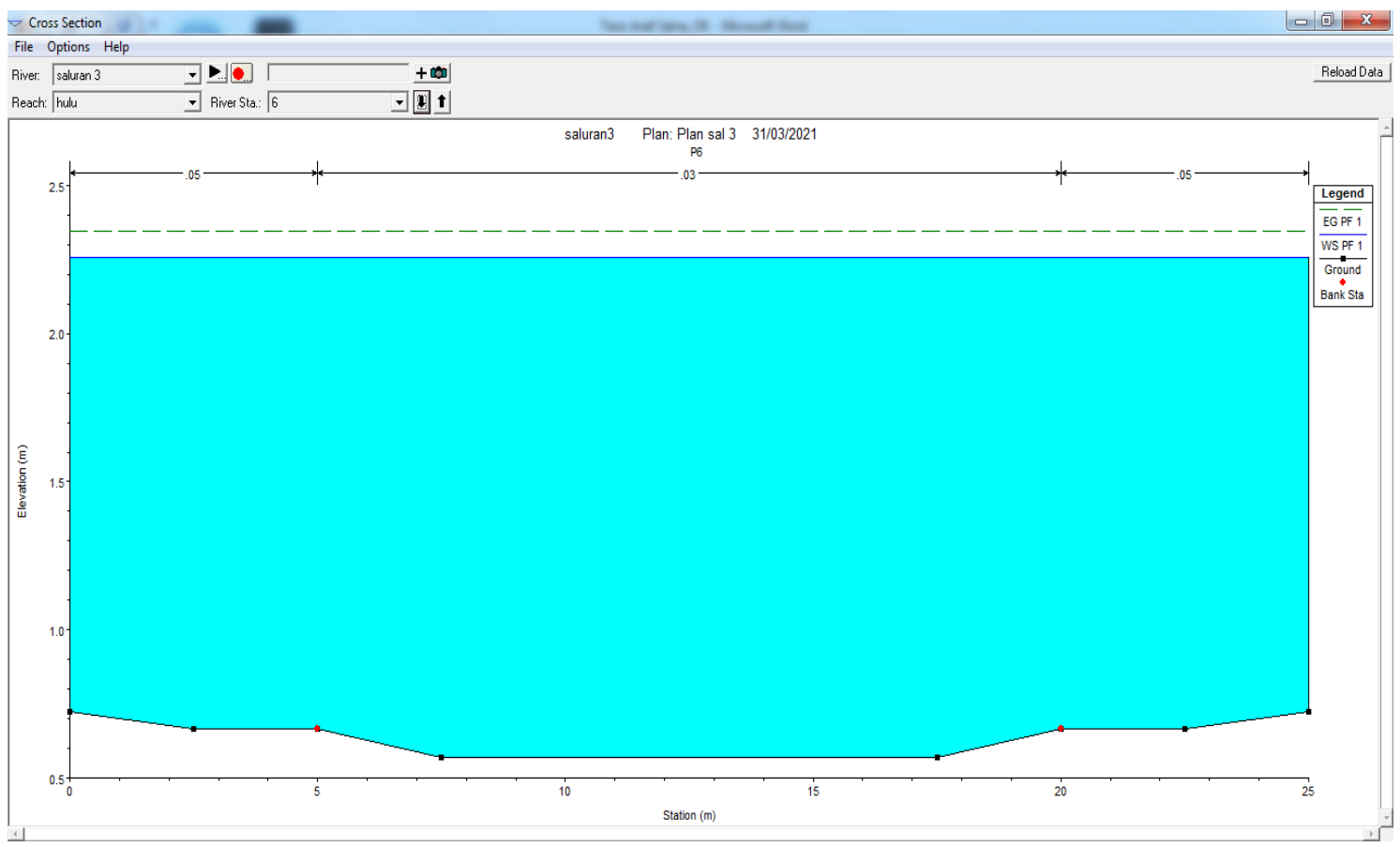

Fig. 8. The pattern of water flow movement in the P-6 channel

In Fig. 8. the channel does not increase the water level in the channel. This means that the P-6 channel does not overflow and has a little effect due to a storage pool, increasing flow in the channel.

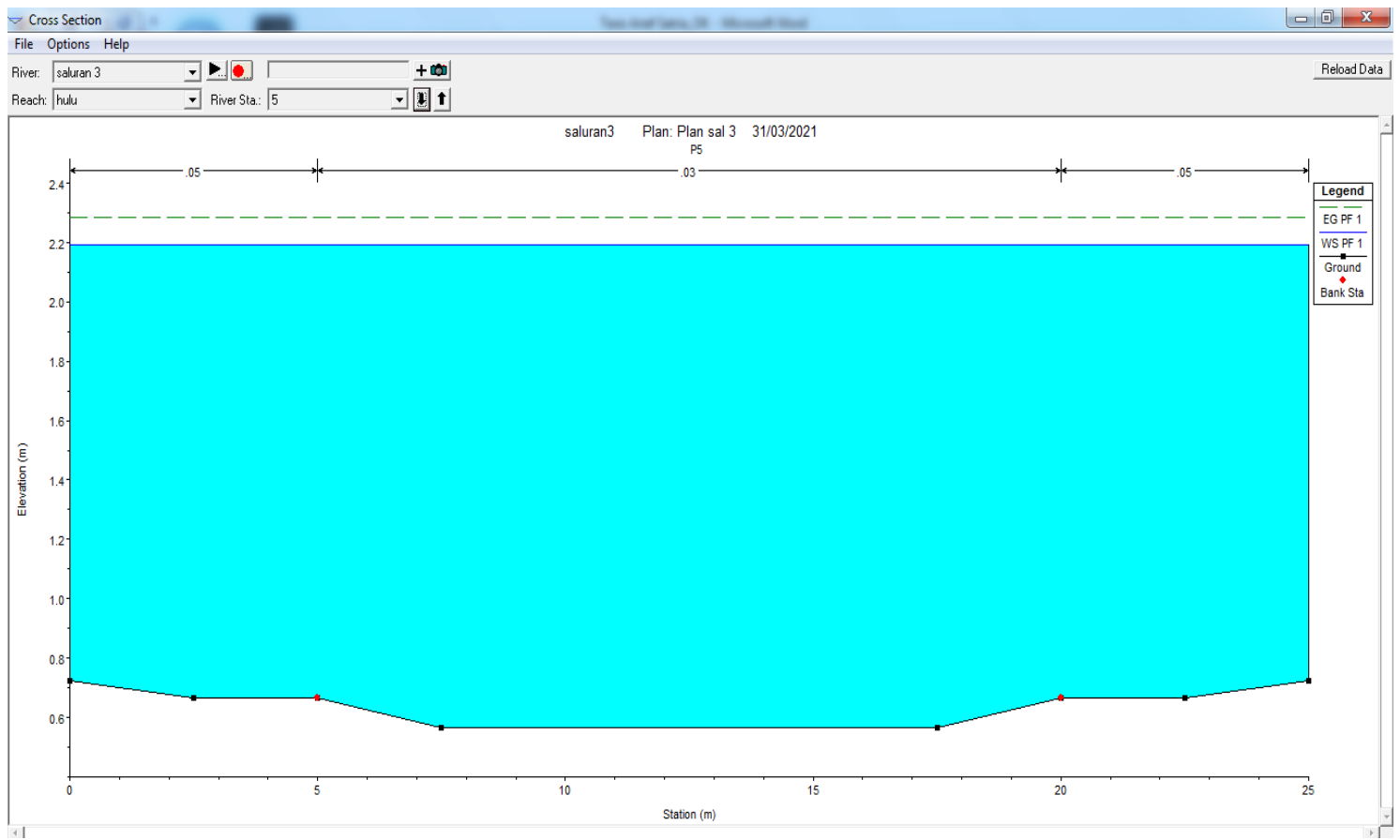

Fig. 9. The pattern of water flow movement in the P-5 channel

In Fig. 9. the channel does not increase the water level in the channel. This means that the P-5 channel does not overflow and has a little effect due to a storage pool, increasing flow in the channel. 


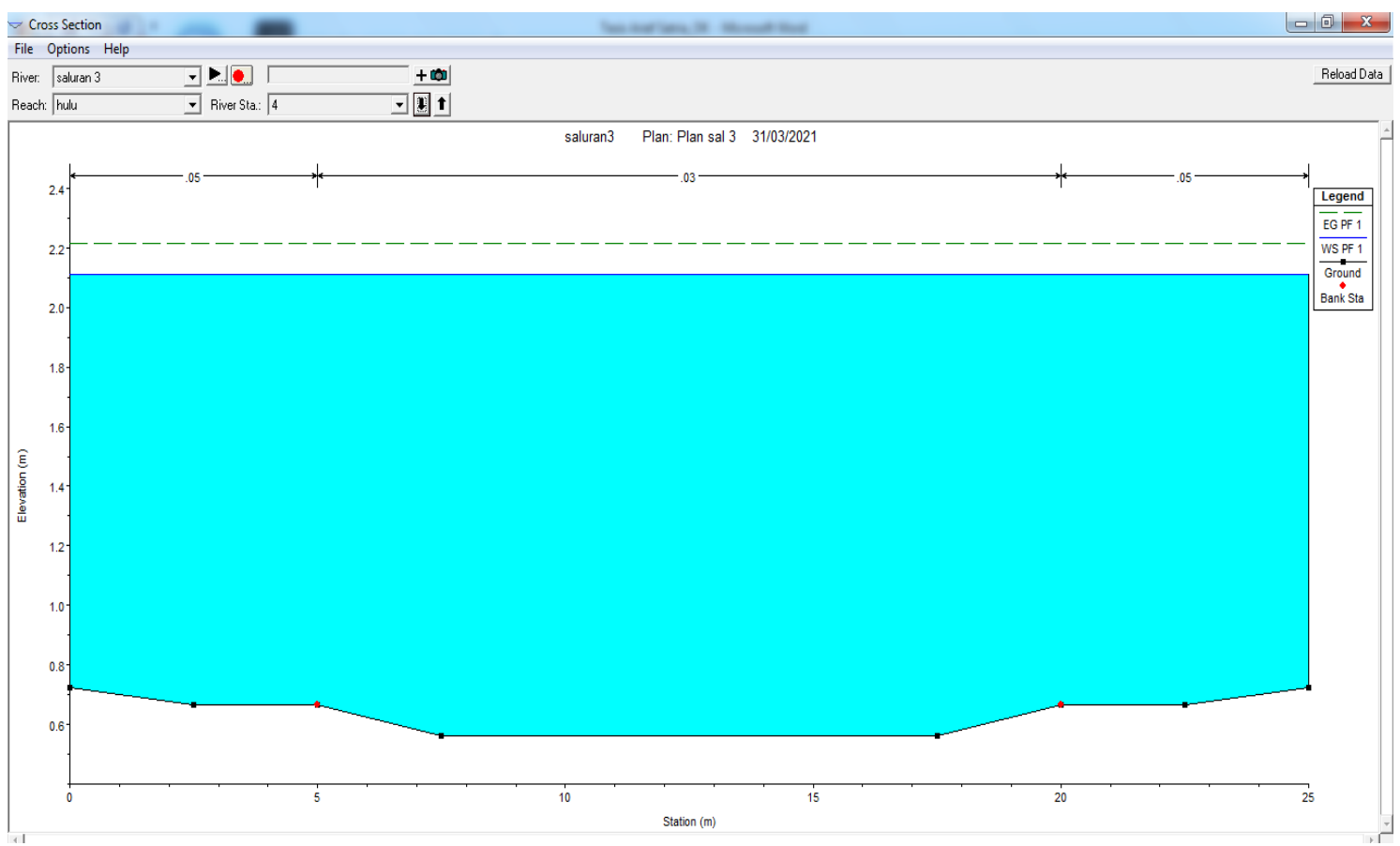

Fig. 10. The pattern of water flow movement in the P-4 channel

In Fig. 10, the channel does not increase the water level in the channel. This means that the P-4 channel does not overflow and has a little effect due to a storage pool, increasing flow in the channel.

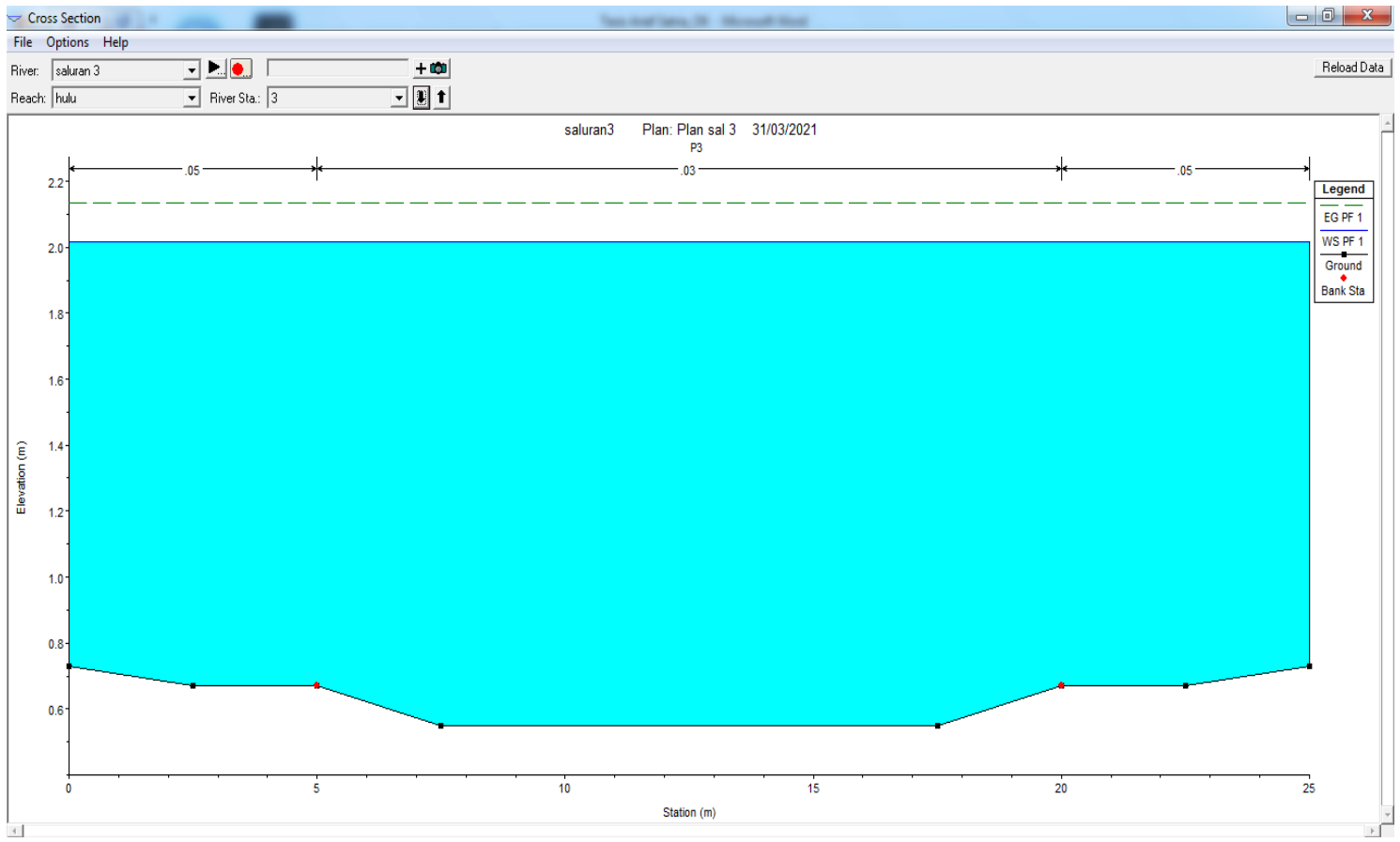

Fig. 11. The pattern of water flow movement in the P-3 channel

In Fig. 11, the channel does not increase the water level in the channel. This means that in the P-3 channel, there is no overflow, and it has a little effect due to the presence of a storage pool, increasing flow in the channel. 


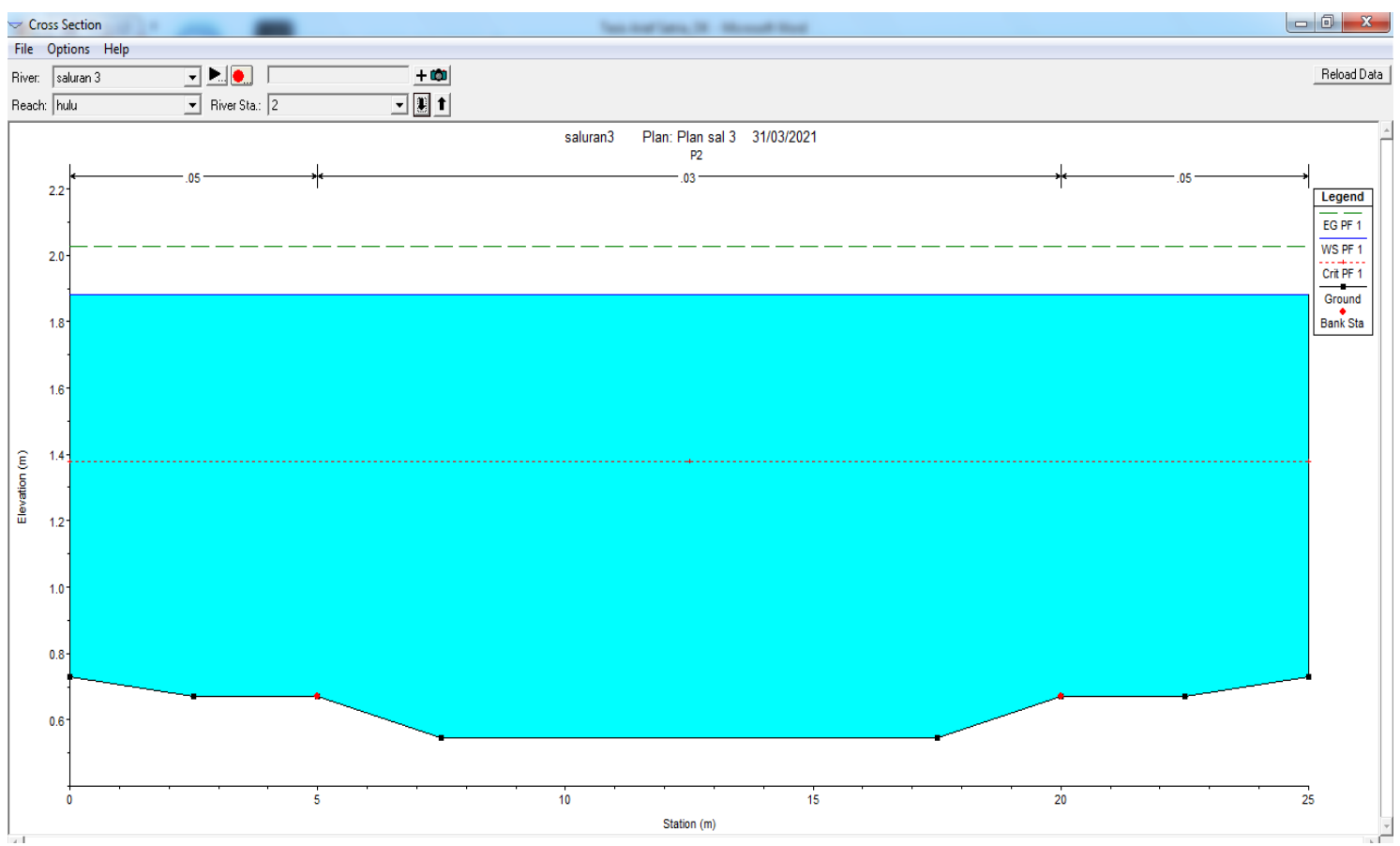

Fig. 12. The pattern of water flow movement in the P-2 channel

In Fig. 12, it can be seen that the channel does not increase the water level in the channel. This means that the P-2 channel does not overflow and has a little effect due to a storage pool, increasing flow in the channel.

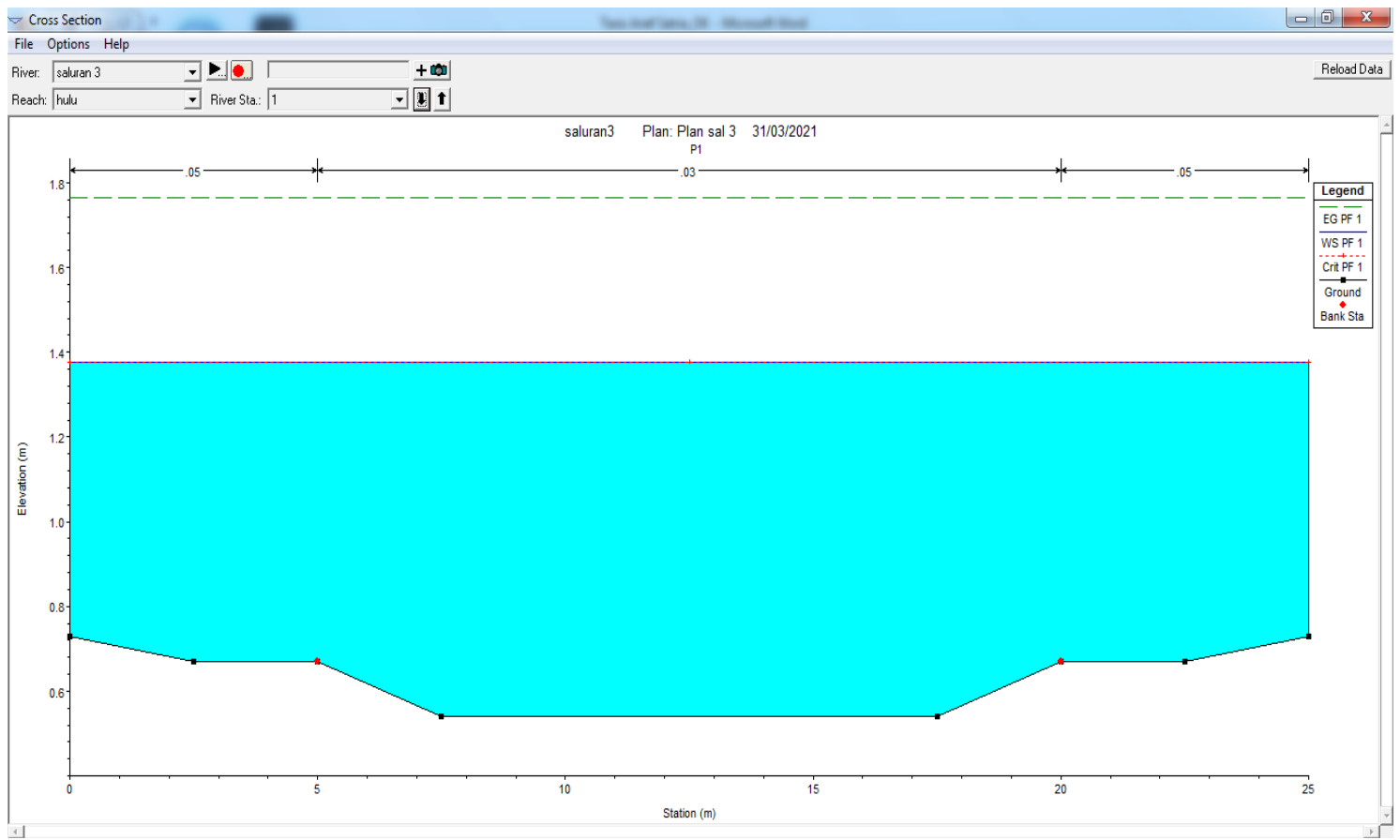

Fig. 13. The pattern of water flow movement in the P-1 channel

In Fig. 13, the channel does not increase the water level in the channel. This means that the P-1 channel does not overflow and has a little effect due to a storage pool, increasing flow in the channel. 


\section{CONCLUSION}

The average diameter $\left(\mathrm{d}_{50}\right)$ used as sediment in the channel is $0.025 \mathrm{~mm}$ in diameter based on the result results of the sieve analysis in the soil mechanics laboratory. The water drainage channel of the former coal mine, the Pit-3 channel, west Banko, Tanjung Enim, both at the profile (P-1) to (P-10), is still safe or the condition of the channel is stable. Soo, it is concluded that there is no overflow in the channel body based on the results. Analysis with the HEC-RAS program.

\section{ACKNOWLEDGEMENT}

We would like to thanks the Rector of Universitas Bina Darma for support.

\section{REFERENCES}

[1] Soenarno, (2014)., Application of Irrigation Service Fee Towards Meeting O\&M Cost in Indonesia 15th: Congress of ICID. The Hague.

[2] Syarifudin.,A, (2018), Hidrologi Terapan (Applied Hydrology), Andi Publisher, Yogyakarta, p. $45-48$

[3] Syarifudin, A, (2018), Drainase Perkotaan Berwawasan Lingkungan (Environmentally Urban Drainage), Andi Publisher, Yogyakarta, p. 38-42

[4] Suripin., 2004, Sustainable Urban Drainage Systems, Andi Publisher, p. 176-179.

[5] Suwandi, Awang, (2004), Open Mine Planning Training, Bandung Islamic University, Bandung, Indonesia

[6] Baitullah Al Amin, M., (2016), Introduction to the short tutorial of HEC-CRAS, Faculty ofEngineering, Department of Civil Engineering, Sriwijaya University.

[7] Syarifudin., A, (2017), The influence of Musi River Sedimentation to The Aquatic Environment DOI: 10.1051 / matecconf / 201710104026, MATEC Web Conf, 101, 04026, [published online 09 March 2017]

[8] Syarifudin A and Dewi Sartika, (2019), A Scouring Patterns Around Pillars of Sekanak River Bridge, Journal of Physics: IOP Conference Series, volume 1167, IOP Publishing

[9] Cahyono Ikhsan., (2017), The effect of flow rate variations at the bottom of an open channel with uniform flow, Civil Engineering Media.

[10] Directorate General of Human Settlements, Ministry of Public Works. (2010). Procedures for Making Retention Ponds and Polders with Main Channels. Directorate General of Human Settlements, Ministry of Public Works. Jakarta.

[11] Istiarto, (2012), River Engineering, Gadjahmada University, Yogyakarta

[12] Narulita, I., (2016), Spatial and temporal distribution of rainfall in the Cerucuk watershed, Belitung Island. Research and Mining Journal, Vol. 26 No. 2: 141 - 154

[13] Paimin et al, (2012), Watershed Management Planning System, Research and Development Center for Conservation and Rehabilitation (P3KR), Bogor, Indonesia

[14] Robert. J. Kodoatie, Sugiyanto., (2002), Flood causes and methods of control in an environmental perspective, Yogyakarta

[15] Riztri Bonita and Mas Agus Mardyanto, (2015), Study of Groundwater Water Balance in Kejayan District, Pasuruan Regency, East Java Province, Department of Environmental Engineering, Faculty of Civil Engineering and Planning, Sepuluh Nopember Institute of Technology (ITS), JURNAL ENGINEERING ITS Vol. 4, No. 1

[16] Syarifudin A, HR Destania., (2020), IDF Curve Patterns for Flood Control of Air Lakit river of Musi Rawas Regency, IOP Conference Series: Earth and Environmental Science Volume 448, 2020, The 1st International Conference on Environment, Sustainability Issues and Community Development 23 - 24 October 2019, Central Java Province, Indonesia

[17] Syarifudin A., (2014), The 2nd International Conference on Informatics, Environment, Energy, and Applications (IEEA 2013), Bali, Indonesia, March 16-17, 2013, JOCET (Journal of Clean Energy and Technology) Journal ISSN: 1793-821X Vol. 2, No. 1, January 2014. 
[18] Wanshun Zhang, Yanhong Xu, Yanru Wang, and Hong Peng, (2014). Modeling Sediment Transport and River Bed Evolution in River System, Journal of Clean Energy Technologies, Vol. 2, No. 2, April 2014 